\title{
Characterization of carbonaceous aerosols over the East China Sea: The impact of the East Asian continental outflow
}

\author{
Fengwen Wang ${ }^{a}$, Zhigang Guo ${ }^{\text {a, }}{ }^{*}$, Tian Lin ${ }^{b}$, Limin $\mathrm{Hu}^{\mathrm{c}}$, Yingjun Chen ${ }^{\mathrm{d}}$, Yifang Zhu ${ }^{\mathrm{e}}$ \\ a Shanghai Key Laboratory of Atmospheric Particle Pollution and Prevention, Department of Environmental Science and Engineering, Fudan University, \\ Shanghai 200433, China \\ ${ }^{\mathrm{b}}$ State Key Laboratory of Environmental Geochemistry, Institute of Geochemistry, Chinese Academy of Sciences, Guiyang 550002, China \\ ${ }^{\text {c } K e y ~ L a b o r a t o r y ~ o f ~ M a r i n e ~ S e d i m e n t o l o g y ~ a n d ~ E n v i r o n m e n t a l ~ G e o l o g y, ~ F i r s t ~ I n s t i t u t e ~ o f ~ O c e a n o g r a p h y, ~ S t a t e ~ O c e a n i c ~ A d m i n i s t r a t i o n, ~ Q i n g d a o ~ 266061, ~}$ \\ China \\ ${ }^{\mathrm{d}}$ Key Laboratory of Coastal Zone Environmental Processes, Yantai Institute of Coastal Zone Research, Chinese Academy of Sciences, Yantai 264003, China \\ e Department of Environmental Health Sciences, Jonathan and Karin Fielding School of Public Health, University of California, Los Angeles, CA 90095-1772, \\ USA
}

\section{H I G H L I G H T S}

- An obvious seasonal variation of carbonaceous aerosols was observed.

- PM2.5 contained approximately 84\% of carbonaceous aerosols in TSP.

- The sea spray aerosol (SSA) played a key role on $n$-alkanes in winter.

- POC and EC dominated in cold season due to Asian continental outflow.

\section{A R T I C L E I N F O}

\section{Article history:}

Received 18 November 2014

Received in revised form

26 March 2015

Accepted 28 March 2015

Available online 31 March 2015

\section{Keywords:}

Carbonaceous aerosols

Concentration

Size distribution

Sources

East Asian continental outflow

East China Sea

\begin{abstract}
A B S T R A C T
Seventy-five paired PM2.5 (aerodynamic diameter less than $2.5 \mu \mathrm{m}$ ) and TSP (total suspended particle) samples collected from a pristine island in the East China Sea (ECS) between October 2011 and August 2012 were analyzed for organic carbon (OC), elemental carbon (EC), and $n$-alkanes. The island lies in the pathway of continental outflow from Mainland China to the northwest Pacific Ocean driven by the East Asian Monsoon. The concentrations of OC, EC (in $\mu \mathrm{g} / \mathrm{m}^{3}$ ), and $n$-alkanes (in $\mathrm{ng} / \mathrm{m}^{3}$ ) were highest in winter (means: 4.7, 1.3, 140.1, respectively) and lowest in summer (means: 1.1, 0.3, 17.0, respectively). PM2.5 contained approximately $88 \%$ of the OC, $80 \%$ of the EC, and $61 \%$ of the $n$-alkanes in TSP. Petroleum residue was the dominant contributor to the $n$-alkanes. $C_{12}-C_{22} n$-alkanes with strong even-to-odd predominance observed in winter were attributed to the microbial contribution from sea spray aerosol (SSA) driven by the higher wind speed. There was a higher secondary organic carbon (SOC)/OC ratio in warm seasons (summer and fall) than that in cold seasons (spring and winter). The dominance of primary organic carbon (POC) and EC in cold seasons was possibly mainly due to the influence of the East Asian continental outflow. Three episodes of high concentrations of carbonaceous aerosols were observed, and we focused on the impact of these pollutants from East Asia on the air quality over the ECS. Carbonaceous pollutants were more concentrated in PM2.5 during the fall episode triggered by biomass burning in East China. The winter haze associated with intensive indoor heating in North China brought substantial carbonaceous pollutants, with a minor influence on their size distribution. The dust episode in spring was related to coarse particles (i.e., TSP-PM2.5), yielding a distinctly different size distribution.
\end{abstract}

(C) 2015 Elsevier Ltd. All rights reserved.

\footnotetext{
* Corresponding author.

E-mail address: guozgg@fudan.edu.cn (Z. Guo).
}

\section{Introduction}

Carbonaceous species, which are a mixture of substances containing carbon atoms, comprise a large but highly variable fraction of the aerosol burden in the atmosphere. In general, in the 
atmosphere, these compounds can be classified into two groups: organic carbon (OC) and elemental carbon (EC). OC, formed by a variety of processes including combustion and secondary organic carbon (SOC) formation, is a mixture of hundreds of organic compounds spanning a wide range of chemical and thermodynamic properties. $\mathrm{N}$-alkanes are important components of the $\mathrm{OC}$ fraction, and they are derived from both natural origins and anthropogenic activities (Simoneit, 1986). Waxes from higher plants and two commercial sources, crude oil and natural gas, have been shown to be common sources for $n$-alkanes. EC, produced by incomplete combustion of fossil fuels and biomass burning, is a mixture of graphite-like particles and light-absorbing organic matter.

Carbonaceous aerosols have received increasing attention in recent years due to their adverse effects on human health and climatic change (Highwood and Kinnersley, 2006; Menon et al., 2002), potential importance in a wide range of biogeochemical processes (Schmidt et al., 2001), and possible representation of a notable sink in the global carbon cycle (Jurado et al., 2008). In recent decades, the concentrations of atmospheric carbonaceous pollutants (e.g., OC and EC) in China have been increasing with the rapid industrialization and urbanization, especially in the Yangtze River Delta (YRD) region (Feng et al., 2009). The YRD, covering 1.1\% of the area of China $\left(\sim 99,600 \mathrm{~km}^{2}\right)$, is home to 108 million people (8.1\% of the total population of China). The GDP of the YRD was 8214 billion yuan (renminbi, a Chinese currency unit) in 2011, which represents $17.4 \%$ of the entire Chinese economy (www. hktdc.com). The East China Sea (ECS), located near highly developed regions of China (i.e., the YRD), has been receiving a large influx of pollutants from the Yangtze River and atmospheric deposition (Lin et al., 2013). The air circulation pattern of this region is influenced by the East Asian Monsoon, rendering the ECS a sink of the pollutants transported not only from the YRD but also from North China (Lin et al., 2011; Zhang and Gao, 2007). Therefore, knowledge of the characteristics of anthropogenic pollutants in the aerosols over the ECS would provide useful information to explore the significant role of Asian continental outflow on the ECS and even the northwest Pacific Ocean.

The outflow of East Asian continental pollutants such as dust and organic compounds to the Bohai Sea and Yellow Sea has been investigated in previous studies (Duce et al., 1980; Gao et al., 1997; Feng et al., 2007). There have also been several studies on the occurrence and sources of nutrients, heavy metals in dust, and trace elements in the atmosphere over the ECS (Hsu et al., 2009, 2010; Zhang et al., 2010; Guo et al., 2014). The occurrence of organic and elemental carbon associated with the East Asian outflow was also measured during a cruise campaign in the ECS (Huebert et al., 2004). Nevertheless, the seasonal sources and size of carbonaceous aerosols over the ECS have scarcely been documented. In this study, PM2.5 (aerodynamic diameter less than $2.5 \mu \mathrm{m}$ ) and TSP (total suspended particle) samples were simultaneously collected over four seasons from October 2011 to August 2012 at a remote island in the ECS. Driven by the East Asian Monsoon, the wind pattern arriving at this island (Huaniao Island) is mostly from west to east and north to south. This makes the island an ideal receptor site to explore the effects of continental outflow on the ECS and northwest Pacific Ocean. The objectives of this study are to determine the occurrence and sources of carbonaceous pollutants (i.e., OC, EC, and $n$-alkanes) over four seasons, and to demonstrate the role of continental outflow on carbonaceous aerosols over the ECS.

\section{Materials and method}

\subsection{Sampling site and sample collection}

The aerosol samples were collected at Huaniao Island $\left(30.86^{\circ} \mathrm{N}\right.$, $122.67^{\circ} \mathrm{E}$ ), located $66 \mathrm{~km}$ to the east of the Shanghai coast (Fig. 1). The island has a land area of $3.28 \mathrm{~km}^{2}$ and a population of less than 1000 , most of which is concentrated on the southeast of the island where a wharf is situated. To minimize the influence of local anthropogenic emissions, the sampling apparatus was placed on the rooftop of a three-story building on the northwest side of the island, $\sim 2 \mathrm{~km}$ from the center of population. The elevation of the instrument station was $\sim 50 \mathrm{~m}$ above sea level.

PM2.5 samples were collected using a sampler (Guangzhou Mingye Huanbao Technology Company) (Wang et al., 2014) on quartz filters $\left(20 \times 25 \mathrm{~cm}^{2}, 2500 Q A T\right.$, PALL, USA $)$ at a flow rate of $18 \mathrm{~m}^{3} / \mathrm{h}$. TSP samples were collected using a sampler (Beijing Geological Institute) (Guo et al., 2009) on quartz filters (9 cm in diameter, QM-A, Whatman, UK) at $4.1 \mathrm{~m}^{3} / \mathrm{h}$. A total of 75 paired PM2.5 and TSP samples were obtained from October 23, 2011 to August 20, 2012. Each paired sampling campaign consisted of a 23.5-h sampling period, starting at 9:00 am on the first day to 8:30 am of the following day. At least two parallel operational sampling blanks were measured for each season. Sample media for OC and EC were prepared as follows: the filters were wrapped in aluminum foil and baked at $450{ }^{\circ} \mathrm{C}$ for $4 \mathrm{~h}$ to remove residual OC. Subsequently, they were sealed in a marked valve bag and stored in the laboratory prior to sample collection. All post-sampling filters were stored at $-20^{\circ} \mathrm{C}$ for later analysis.

\subsection{Sample analysis}

OC and EC were detected in the aerosol samples using the IMPROVE thermal/optical reflectance (TOR) method using the Desert Research Institute (DRI) Model 2001 Thermal/Optical Carbon Analyzer (Chow et al., 1993). For each sample, a $0.544-\mathrm{cm}^{2}$ punch area was taken to analyze the targeted carbon fractions including four OC $(\mathrm{OC} 1, \mathrm{OC} 2, \mathrm{OC} 3$, and $\mathrm{OC} 4)$ and three EC (EC1, EC2, and EC3) fractions, and a pyrolyzed carbon fraction (OP). These fractions were produced under various temperature and oxidation conditions. OC1, OC2, OC3, and OC4 were formed in a helium atmosphere under a temperature of $140{ }^{\circ} \mathrm{C}, 280{ }^{\circ} \mathrm{C}, 480{ }^{\circ} \mathrm{C}$, and $580^{\circ} \mathrm{C}$, respectively. EC1, EC2, and EC3 were formed in a $2 \%$ oxygen/ $98 \%$ helium atmosphere under a temperature of $580^{\circ} \mathrm{C}, 740{ }^{\circ} \mathrm{C}$, and $840^{\circ} \mathrm{C}$, respectively. OC was operationally defined as total carbon in the sample when heated to $550{ }^{\circ} \mathrm{C}$ in a $100 \%$ helium atmosphere. EC was defined as the total remaining carbon when heated to $800^{\circ} \mathrm{C}$ in an atmosphere of $2 \%$ oxygen and $98 \%$ helium after removal of OC. $\mathrm{OP}$ is defined as the amount of carbon measured after the oxygen is added until the reflectance achieves its original value. Therefore, $\mathrm{OC}$ and EC were obtained as:

$$
\begin{aligned}
& \mathrm{OC} 1+\mathrm{OC} 2+\mathrm{OC} 3+\mathrm{OC} 4+\mathrm{OP}, \text { and } \mathrm{EC} 1+\mathrm{EC} 2+\mathrm{EC} 3 \\
& -\mathrm{OP} \text {, respectively. }
\end{aligned}
$$

The analytical procedure of measurement of $n$-alkanes in aerosols has been described previously (Guo et al., 2009). In brief, half of each filtrate was used for Soxhlet extraction. The extraction lasted $48 \mathrm{~h}$ with dichloromethane (DCM) spiked with mixture of $200 \mathrm{ng}$ of deuterated naphthalene (Nap- $d_{8}, m / z$ 136), deuterated acenaphthene $\left(\right.$ Ace- $\mathrm{d}_{10}, m / z$ 164), deuterated phenanthrene (Phe- $\mathrm{d}_{10}, \mathrm{~m} / z$ 188), deuterated chryene $\left(\mathrm{Chr}-\mathrm{d}_{12}, \mathrm{~m} / z\right.$ 240), and deuterated perylene (Per- $\mathrm{d}_{12}, m / z$ 264) for the recovery rate. The sample extracts were concentrated to $\sim 5 \mathrm{ml}$ using a vacuum rotary evaporator at $40{ }^{\circ} \mathrm{C}, 50 \mathrm{rpm}$. Subsequently, the solvent was exchanged into $n$ hexane (HEX) and was rotary evaporated to approximately $2 \mathrm{ml}$. All samples were then transferred into $22-\mathrm{ml}$ glass cylinder tubes and concentrated to $\sim 2 \mathrm{ml}$ under soft purified $\mathrm{N}_{2}$. The concentrated extracts were sequentially cleaned in a chromatography column filled with $3-\mathrm{cm}$ deactivated alumina $\left(\mathrm{Al}_{2} \mathrm{O}_{3}\right), 3-\mathrm{cm}$ silica gel $\left(\mathrm{SiO}_{2}\right)$ 


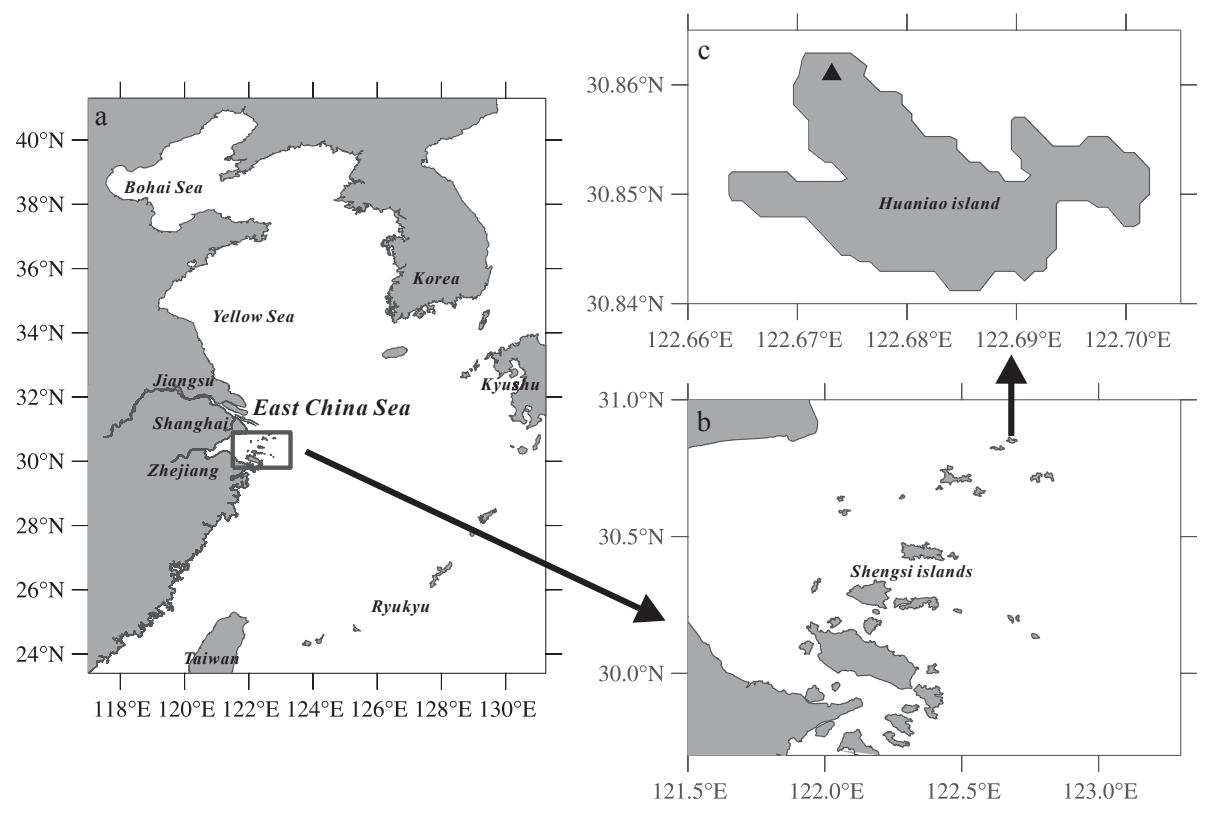

Fig. 1. Sampling site at Huaniao Island in ECS (redrawn from Wang et al., 2014).

and 1-cm anhydrous sodium sulfate $\left(\mathrm{Na}_{2} \mathrm{SO}_{4}\right)$, and eluted with $20 \mathrm{ml} \mathrm{DCM} / \mathrm{HEX}(1: 1, \mathrm{v}: \mathrm{v})$. Prior to analysis for $n$-alkanes, the extracts were reduced to $\sim 500 \mu$ l under a stream of purified $N_{2}$. A sample vial $(2 \mathrm{ml})$ was prepared for the final concentrated extract, and hexamethylbenzene (HMB) was used as an internal standard to quantify the $n$-alkanes.

Gas chromatography mass spectrometer (GC-MS) analysis: all samples were injected with HMB and then concentrated to $200 \mu \mathrm{l}$ in preparation for GC-MS analysis. The GC-MSD (Agilent GC $6890 \mathrm{~N}$ coupled with a 5975C MSD, equipped with a DB5-MS column, $30 \mathrm{~m} \times 0.25 \mathrm{~mm} \times 0.25 \mu \mathrm{m}$ ) used helium as the carrier gas. The GC operating processing was: held at $60{ }^{\circ} \mathrm{C}$ for $2 \mathrm{~min}$, ramped to $290{ }^{\circ} \mathrm{C}$ at $3{ }^{\circ} \mathrm{C} / \mathrm{min}$ and held for $20 \mathrm{~min}$. The sample was injected split-less with the injector temperature at $290{ }^{\circ} \mathrm{C}$. The post-run time was 5 min with the oven temperature at $310^{\circ} \mathrm{C}$.

\subsection{Quality assurance and quality control $(Q A / Q C)$}

The $\mathrm{QA} / \mathrm{QC}$ procedures for the $\mathrm{OC}$ and $\mathrm{EC}$ measurements included the following: a set quantity of sucrose $(10.56 \mu \mathrm{g})$ was used to calibrate the analyzer every day with a difference of $<6 \%$ for the recovery rate. One replicate analysis was conducted for every 10 samples. The difference determined from replicate analyses was $<5 \%$ for TC (total carbon, sum of OC and EC), and $6 \%$ for OC and EC (4.5\% and $4.7 \%$, respectively). Two parallel blank filters were analyzed following identical procedures for each season for both PM2.5 and TSP. The results were corrected relative to the average blank concentrations. The limit of detection (LOD) of OC and EC was calculated as three times the standard deviation of the blank filters. The LOD for OC and EC were calculated as 0.2 and $0.03 \mu \mathrm{g} / \mathrm{m}^{3}$, respectively, based on the flow rate of the PM2.5 and TSP samplers. The standard $n$-alkanes were purchased from Accu Standard, Inc. (USA). The QA/QC for $n$-alkanes was based on the recovery rate of Phe- $\mathrm{d}_{10}$ and $\mathrm{Chr}-\mathrm{d}_{12}$. These two species were assumed to have equal molecular weight and similar chemical properties to the targeted $n$-alkanes (Guo et al., 2009), which were those from $\mathrm{C}_{14} \mathrm{H}_{30}$ to $\mathrm{C}_{33} \mathrm{H}_{68}$. The mean recoveries for PM2.5 samples were $91 \% \pm 13 \%$ for Phe- $\mathrm{d}_{10}$, and $103 \% \pm 15 \%$ for Chr- $\mathrm{d}_{12}$. For TSP, they were $85 \% \pm 12 \%$ for Phe- $\mathrm{d}_{10}$, and $101 \% \pm 12 \%$ for Chr- $\mathrm{d}_{12}$. Procedural blanks, standard-spiked blanks, and matrix were analyzed, and the results met $\mathrm{QA} / \mathrm{QC}$ requirements. Sample results were calculated as blank corrections by subtracting an average blank from each sample.

\subsection{Air mass back-trajectory analysis}

Air mass back-trajectory is a common method used to trace the atmospheric transport path. Three-day back trajectories from the sampling site were calculated at $700 \mathrm{~m}$ above ground level at 1200 UTC at 12-h intervals for all sampling days. The HYSPLIT Trajectory Model from the National Oceanic and Atmospheric Administration (NOAA) (http://ready.arl.noaa.gov/hysplit-bin/trajasrc.pl) was used as the database.

\section{Results and discussion}

\subsection{Back-trajectory and meteorological conditions}

During the sampling period, ambient temperatures on the island ranged from 10 to $24{ }^{\circ} \mathrm{C}$ (average $18{ }^{\circ} \mathrm{C}$ ) in fall, $-1-12{ }^{\circ} \mathrm{C}$ (average $7{ }^{\circ} \mathrm{C}$ ) in winter, $9-24{ }^{\circ} \mathrm{C}$ (average $14{ }^{\circ} \mathrm{C}$ ) in spring, and $25-32{ }^{\circ} \mathrm{C}$ (average $28{ }^{\circ} \mathrm{C}$ ) in summer. The three-day back-trajectories from an altitude of $700 \mathrm{~m}$ for the sampling periods are shown in Fig. 2. In summer, most air parcels arriving at Huaniao Island were from the east (open sea), whereas air parcels in winter were transported from northern China (Inner Mongolia, Northeastern Provinces), bringing anthropogenic emissions (i.e., coal and biomass burning, vehicle exhaust, etc.). In spring and fall, the air masses mostly originated from the land with some from the sea, and the wind direction varied between northwest to north and southeast to south. Therefore, the atmosphere above Huaniao Island during the sampling period, in spring, fall, and winter, was influenced by regions around the YRD and continental air transport from northern China.

\subsection{Concentrations of carbonaceous aerosols}

The average concentrations of OC and EC in PM2.5 and TSP for 

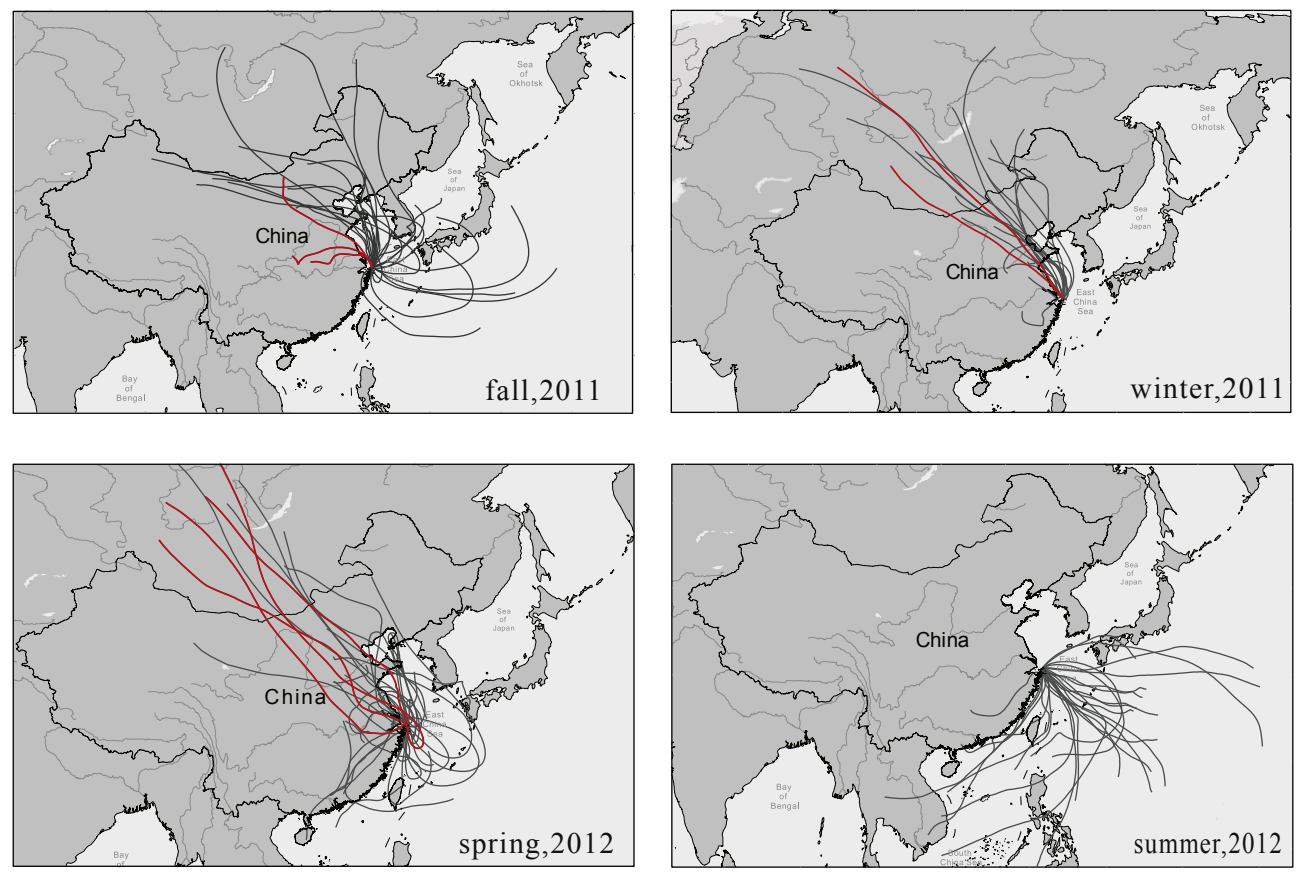

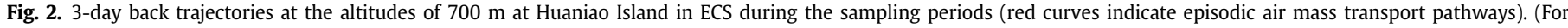
interpretation of the references to colour in this figure legend, the reader is referred to the web version of this article.)

each season are shown in Table 1 . The concentrations of OC, EC, and $n$-alkanes in all aerosol samples are shown in Table S1. The average concentrations of OC (in $\mu \mathrm{g} / \mathrm{m}^{3}$ ) in PM2.5 ranged from $1.0 \pm 0.4$ in summer to $3.9 \pm 2.5$ in winter. In TSP, they ranged from $1.1 \pm 0.6$ in summer to $4.7 \pm 5.0$ in winter. EC, based on the annual mean, was three-to four-fold lower than the corresponding OC. Based on the ratios of the concentrations of $\mathrm{OC}$ and EC in PM2.5 relative to those in TSP, approximately $88 \%$ OC and $80 \%$ EC were concentrated in PM2.5. Therefore, compared with coarse particles (i.e., TSP-PM2.5), carbonaceous aerosols possibly play a more significant role in the formation of fine particles (i.e., PM2.5). The seasonal variation in OC and EC in PM2.5 and TSP is shown in Fig. 3. The $\mathrm{R}^{2}$ value between OC and EC in PM2.5 was 0.91, and in TSP it was 0.95, suggesting possible common sources. The seasonal difference in carbonaceous aerosols over the ECS could mainly be attributed to the prevailing long-range transport of air masses in each season as well as possible changes in meteorological conditions. The lowest concentrations in summer were due to the relatively "clean" origin air and high washout effect of rainfall. Rain scavenges OC more effectively since OC species are more hydrophilic than EC species; EC are generally hydrophobic. However, when EC species are freshly emitted and then "matured" (i.e., through contact with marine sulfate or sea salt), they become hydrophilic and are therefore scavenged by rain (Safai et al., 2014). In winter, in addition to the extensive "input" of carbonaceous pollutants from the continental landmass (Fig. 2), the low dispersal efficiency of airborne particles

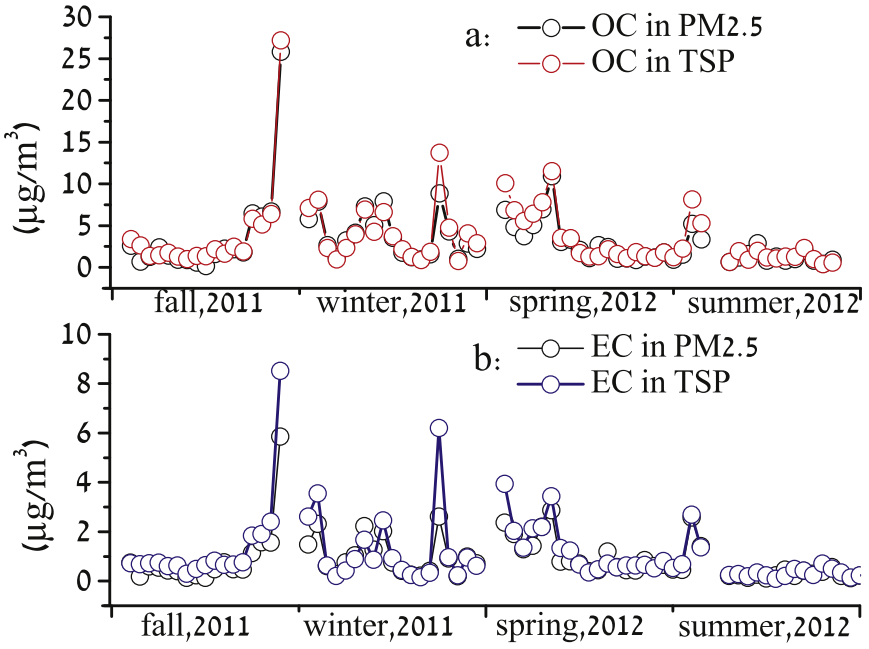

Fig. 3. Seasonal variations of OC and EC concentrations in PM2.5 and TSP.

under conditions of low mixing heights also gave rise to the high concentrations of OC and EC.

Table 2 shows the concentrations of yield $n$-alkanes (sum of $\left.\mathrm{C}_{14}-\mathrm{C}_{33}\right)$ in PM2.5 and TSP and associated key indices. The average concentrations of yield $n$-alkanes in PM2.5 $\left(\mathrm{ng} / \mathrm{m}^{3}\right)$ were highest in

Table 1

Concentrations of OC, EC, and SOC $\left(\mu \mathrm{g} / \mathrm{m}^{3}\right)$ and ratios of SOC/OC in PM2.5 and TSP in each season.

\begin{tabular}{|c|c|c|c|c|c|c|c|c|c|c|c|c|c|}
\hline \multirow[t]{2}{*}{ Season } & \multicolumn{3}{|l|}{ OC } & \multicolumn{3}{|l|}{$\mathrm{EC}$} & \multicolumn{2}{|l|}{ OC/EC } & \multicolumn{3}{|l|}{ SOC } & \multicolumn{2}{|c|}{ SOC/OC \% } \\
\hline & PM2.5 & TSP & $\%$ & PM2.5 & TSP & $\%$ & PM2.5 & TSP & PM2.5 & TSP & $\%$ & PM2.5 & TSP \\
\hline Fall & 3.6 & 3.8 & 93.6 & 0.9 & 1.3 & 64.6 & 3.5 & 2.8 & 2.3 & 2.5 & 92.0 & 63.9 & 65.8 \\
\hline Winter & 3.9 & 4.7 & 83.5 & 1.0 & 1.3 & 80.9 & 4.0 & 4.2 & 0.9 & 1.8 & 50.0 & 23.1 & 38.3 \\
\hline Spring & 3.1 & 3.7 & 83.7 & 1.1 & 1.3 & 88.1 & 2.8 & 2.8 & 1.5 & 1.6 & 93.8 & 48.4 & 43.2 \\
\hline Summer & 1.0 & 1.1 & 92.0 & 0.2 & 0.3 & 83.7 & 6.1 & 4.2 & 0.8 & 0.9 & 88.9 & 80.0 & 81.8 \\
\hline
\end{tabular}


Table 2

Concentrations of yield $n$-alkanes and associated important indices in PM2.5 and TSP in each season.

\begin{tabular}{|c|c|c|c|c|c|c|c|c|c|c|c|c|c|}
\hline \multirow[t]{2}{*}{ Season } & \multicolumn{3}{|c|}{ Yield $n$-alkanes $\mathrm{ng} / \mathrm{m}^{3}$} & \multicolumn{3}{|c|}{ Petroleum residue $\mathrm{ng} / \mathrm{m}^{3}$} & \multicolumn{2}{|l|}{$\mathrm{C}_{\max }$} & \multicolumn{2}{|l|}{ CPI } & \multicolumn{3}{|c|}{$\begin{array}{l}\text { Plant wax } n \text {-alkanes } \\
\mathrm{ng} / \mathrm{m}^{3}\end{array}$} \\
\hline & PM2.5 & TSP & $\%$ & PM2.5 & TSP & $\%$ & PM2.5 & TSP & PM2.5 & TSP & PM2.5 & TSP & $\begin{array}{l}\text { PM2.5/TSP } \\
\%\end{array}$ \\
\hline Fall & 37.6 & 93.5 & 40.1 & 31.0 & 82.8 & 37.4 & $\mathrm{C}_{27} / \mathrm{C}_{29}$ & $\mathrm{C}_{27} / \mathrm{C}_{28}$ & 1.3 & 1.2 & 6.6 & 10.7 & 61.7 \\
\hline Winter & 78.7 & 140.1 & 56.2 & 76.1 & 135.7 & 56.1 & $\mathrm{C}_{23} / \mathrm{C}_{25}$ & $\mathrm{C}_{22} / \mathrm{C}_{23}$ & 0.8 & 1.0 & 2.6 & 4.4 & 59.1 \\
\hline Spring & 44.9 & 67.2 & 66.8 & 38.6 & 53.4 & 72.3 & $\mathrm{C}_{26} / \mathrm{C}_{27}$ & $\mathrm{C}_{28} / \mathrm{C}_{29}$ & 1.4 & 1.5 & 6.3 & 13.8 & 45.7 \\
\hline Summer & 13.4 & 17.0 & 78.8 & 12.2 & 14.8 & 82.4 & $\mathrm{C}_{30} / \mathrm{C}_{31}$ & $\mathrm{C}_{31} / \mathrm{C}_{33}$ & 1.2 & 1.6 & 1.2 & 2.2 & 54.5 \\
\hline
\end{tabular}

winter $(78.7 \pm 31.0)$ and lowest in summer $(13.4 \pm 5.5)$. In TSP, they were $17.0 \pm 8.4$ in summer, and $140.1 \pm 74.5$ in winter. The PM2.5/ TSP for $n$-alkanes in fall, winter, spring, and summer was $40.1 \%$, $56.2 \%, 66.8 \%$, and $78.8 \%$, respectively, with an annual average of $60.5 \%$. Fig. 4 shows the seasonal variation of each $n$-alkane in PM2.5 and TSP. The maximum carbon number $\left(\mathrm{C}_{\max }\right)$ was similar between PM2.5 and TSP over the four seasons. However, a markedly different pattern was observed in winter compared with the other seasons. The $\mathrm{C}_{\max }$ was characterized by $\mathrm{C}_{22}-\mathrm{C}_{25}$ in winter, whereas in the other seasons it was dominated by high carbon numbers $\left(C_{27}-C_{31}\right)$. In addition, the low-carbon-number $n$-alkanes $\left(C_{14}-C_{22}\right)$ in winter displayed an even carbon-number dominance. It was observed that the dominance in PM2.5 was less marked compared
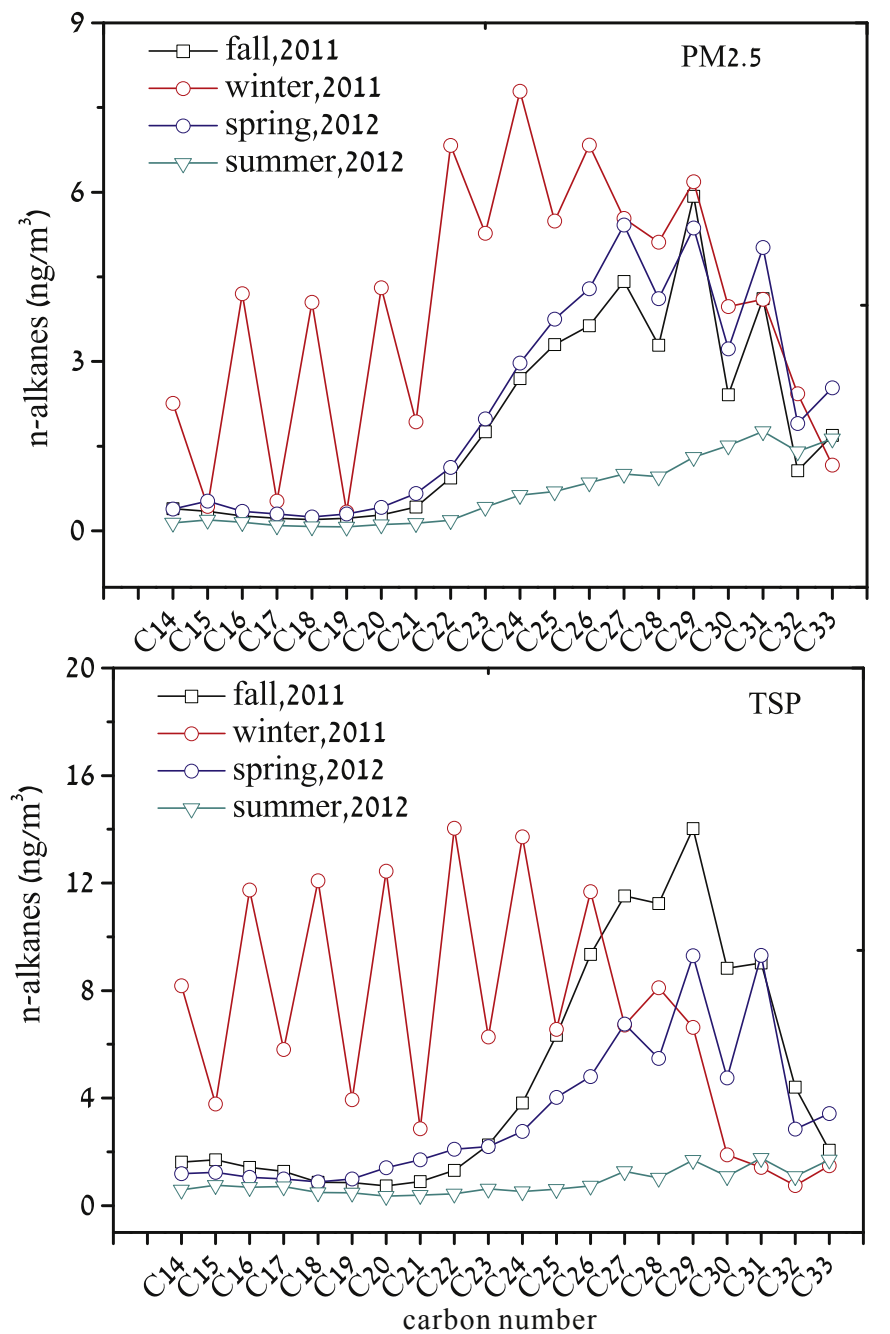

Fig. 4. Seasonal variations of each $n$-alkanes quantified in PM2.5 and TSP. to that in TSP (Fig. 4), suggesting a possible significant source of even-carbon-number $n$-alkanes in coarse particles (i.e., TSPPM2.5). In contrast, this even-to-odd dominance of short-chain $n$ alkanes was not observed in PM2.5 samples simultaneously collected in Shanghai (Fig. 5). Such a difference indicates that the even number of short chain $n$-alkanes in PM2.5 over the ECS possibly has specific sources. Fig. 6 shows the GC-MS chromatograms and typical histogram of $n$-alkane concentrations in a paired PM2.5 and TSP sample in winter. The even carbon number preference of $C_{12}-C_{22}$ is associated with marine bacteria, fungi and yeast species (Grimalt and Albaiges, 1987), and possible petroleumderived inputs, such as petroleum residue (Harji et al., 2008). It has been suggested that marine aerosols could be derived from the bubble bursting upon breaking waves on the ocean surface, which is also known as sea spray (Ault et al., 2014). Sea spray aerosol (SSA) plays a key role in influencing inorganic and organic aerosol burden over much of the Earth's surface (Salter et al., 2014). As early as the 1950s, Woodcock (1953) reported that wind speed was the major driver for sea spray in aerosol production. Later, a series of studies demonstrated that SSA is predominately formed by the action of the wind on the ocean (O'Dowd and Smith, 1993; Nilsson et al., 2001). In the present study, the average wind speed was highest in winter over the four seasons. Thus, the microbial contribution from sea spray was possibly most important in contributing to the organic aerosols under these strong wind effects. Hu et al. (2012) reported that the even-to-odd dominance of short-chain $n$-alkanes in sediments in the ECS is likely related to the presence of microbial biodegradation potentially enhanced by recent fossil fuel inputs. Our previous study at the sampling site revealed that in winter petroleum residue was a notable contributor for PM2.5-

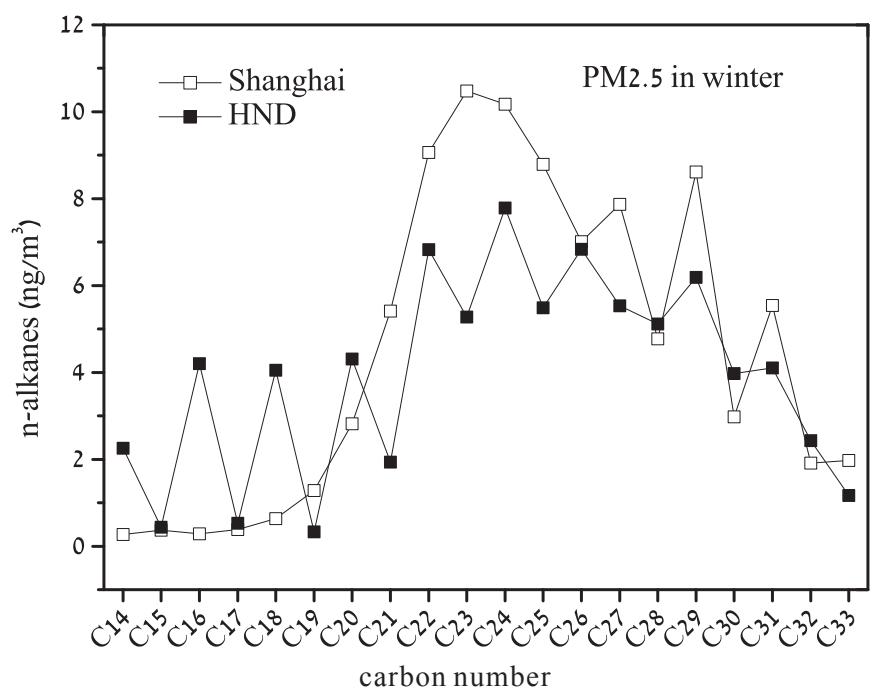

Fig. 5. Variations of the $n$-alkanes in PM2.5 of Huaniao Island and Shanghai in winter. 

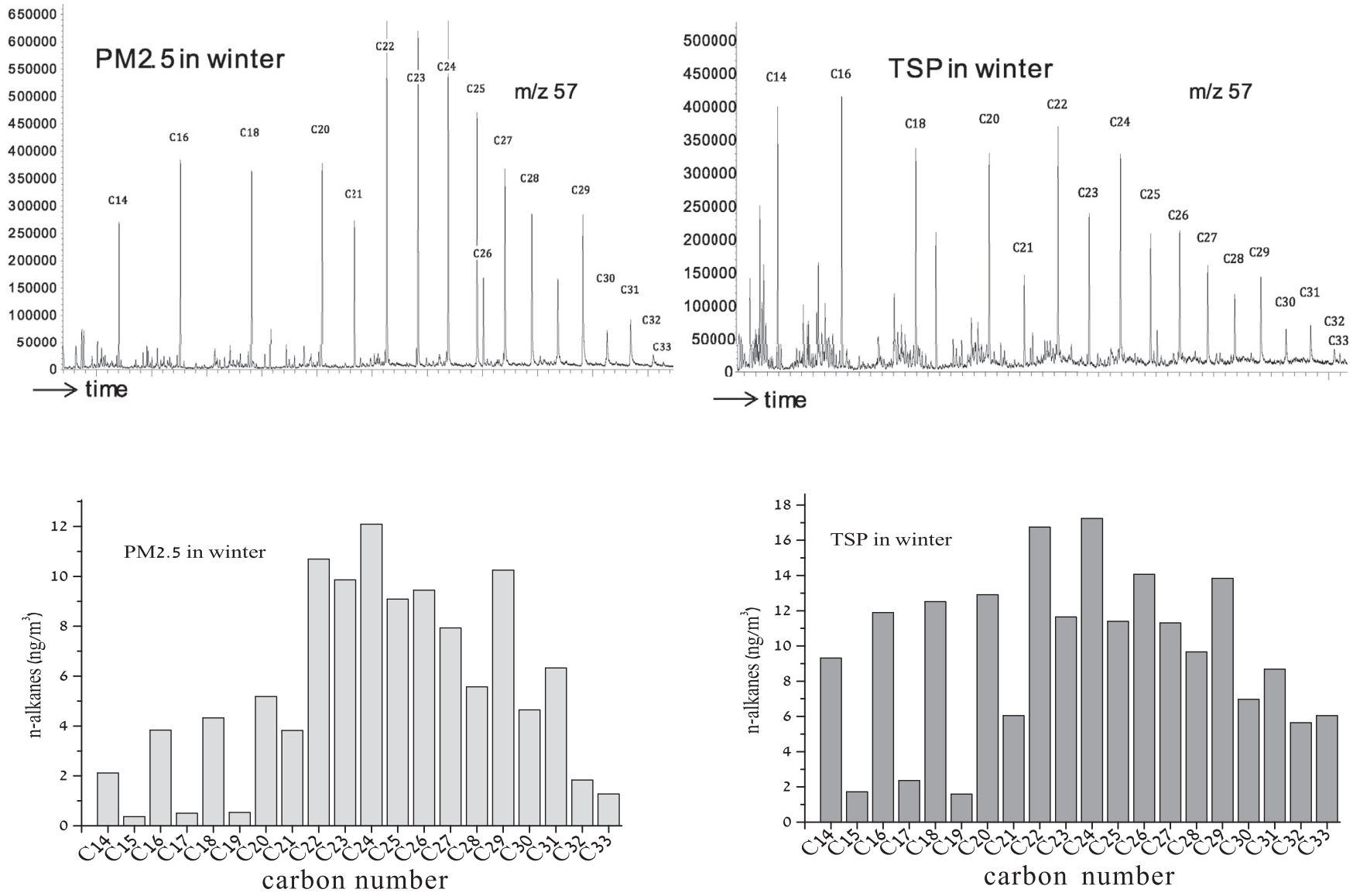

Fig. 6. Typical GC-MS chromatograms and concentration histograms of $n$-alkanes in a paired PM2.5 and TSP samples in winter.

bound PAHs (Wang et al., 2014). Therefore, this dominance was likely due to the marine microbial contribution from SSA that was potentially enhanced by petroleum residue sources from continental outflow.

The carbon preference index (CPI) of $n$-alkanes has been used to identify the distribution of biogenic origins and anthropogenic materials (Simoneit, 1986). In the present study, the CPI was calculated as the sum of the concentrations of the odd-carbonnumber $n$-alkanes divided by the sum of the concentrations of the even-carbon-number n-alkanes, which is:

$\mathrm{CPI}=\sum\left(\mathrm{C}_{15}-\mathrm{C}_{33}\right) / \sum\left(\mathrm{C}_{14}-\mathrm{C}_{32}\right)$

The CPI range was $0.8-1.4$ for PM2.5, and 1.0-1.6 for TSP, with no significant difference. An equal CPI indicates fossil fuel residues (Simoneit, 1986). Therefore, anthropogenic sources contributed substantially to the atmospheric $n$-alkanes in the atmosphere over the ECS. The sources of $n$-alkanes can be generally divided into two categories: plant wax and petroleum residue (Simoneit, 1986). The petroleum residue contributions ranged from $82.4 \%$ in fall to $96.7 \%$ in winter for PM2.5, and from $79.5 \%$ in spring to $96.9 \%$ in winter for TSP. Based on the four seasonal data sets, petroleum residue contributed $89.0 \%$ of the $n$-alkanes in PM2.5, and $88.0 \%$ in TSP. The PM2.5/TSP for petroleum-derived $n$-alkanes in fall, winter, spring, and summer was $37.4 \%, 56.1 \%, 72.3 \%$, and $82.4 \%$, respectively, with an annual mean of $62.1 \%$. The lower PM2.5/TSP ratio of the petroleum-derived $n$-alkanes in fall and winter indicates higher concentrations of petroleum-derived $n$-alkanes residing in the TSPPM2.5.
Carbonaceous aerosols were highest in winter and lowest in summer. Similar seasonal variations were also observed at Changdao Island (Feng et al., 2007), Beijing (He et al., 2001), and Shanghai (Feng et al., 2009). Table 3 shows a comparison of the concentrations and characteristics of OC, EC, and $n$-alkanes at Huaniao Island with those studied elsewhere worldwide. The concentrations of OC, EC and $n$-alkanes over the ECS were lower than those at Changdao Island (Feng et al., 2007), but comparable to observations at another coastal site in Japan (Simoneit et al., 2004). The concentrations at Huaniao Island were far higher compared than those observed at the subtropical islands along the eastern margin of the ECS adjacent to the Pacific (Amami and Miyako Islands) (Kaneyasu and Takada, 2004).

\subsection{Secondary organic carbon (SOC)}

When the OC/EC ratios exceed 2.0, the relationship between OC and EC can be used to estimate the SOC (Chow et al., 1996) and the origin of the carbonaceous particles (Turpin and Huntzicker, 1995). Relatively high OC/EC ratios were reported to be associated with biomass burning (Schauer et al., 2002); whereas lower ratios were observed to characterize vehicle emissions (Saarikoski et al., 2008). In the present study, the average OC/EC ratios in PM2.5 were highest in summer (6.0) and lowest in spring (2.8). In TSP, they were 2.8 in spring and fall, and 4.2 in summer and winter (Table 1 ). An OC/EC ratio below 4 characterizes the dominance of fossil-fuel burning sources for carbonaceous aerosols. The OC/EC ratios $>4$ observed in summer are possibly due to SOC formation or biomass burning. The OC/EC ratios observed in spring were lower than those 
Table 3

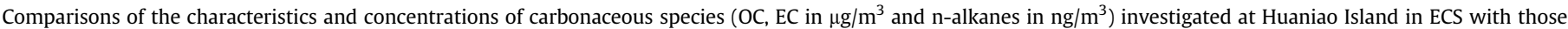
studies elsewhere worldwide.

\begin{tabular}{|c|c|c|c|c|c|c|c|}
\hline Location & Type of site & Description & OC & EC & OC/EC & $n$-alkanes & Reference \\
\hline East China Sea & Remote island & PM2.5 & 2.9 & 0.8 & 4.1 & 43.2 & This study \\
\hline Yellow and Bohai Sea & Coastal island & PM2.5 & 8.4 & 1.8 & 4.8 & 96.2 & Feng et al. (2007) \\
\hline Northwest Pacific Ocean & Remote island & TSP & 4.4 & 1.0 & 5.2 & 39.6 & Simoneit et al. (2004) \\
\hline Around East China Sea & Remote island & PM2 & 0.49 & 0.47 & & & Kaneyasu and Takada (2004) \\
\hline Pearl River Delta Region & Urban areas & PM2.5 & & & 2.5 & & Cao et al. (2004) \\
\hline Northwest Pacific Ocean & Cruise campaign & PM1 & & & 3.3 & & Lim et al. (2003) \\
\hline
\end{tabular}

in winter and summer, possibly due to changes in air masses and meteorological conditions. Fig. 2 shows that, in spring, some of the air masses were transported in an anticlockwise/clockwise fashion across Huaniao Island, a unique transport pathway compared with the other three seasons. The major factor influencing the OC/EC values observed in fall and winter could be continental pollutant outflow via transport of the air mass. In fall, crops including cotton, rice, and wheat are harvested, but their straw residues are discarded and burned (Gustafsson et al., 2009; Rajput et al., 2011). Burning of these crops emits high concentrations of organic compounds. Under prevailing wind patterns, these organic compounds would be transported to the ECS, thus increasing the OC fraction. In winter, less gas/particle partitioning at low temperatures would be another reason for the high OC/EC (Feng et al., 2006). The relatively low OC/EC ratios observed in spring, fall, and winter compared to summer suggest a possible longer residence time for EC than OC under long-range transport from the continent. The OC/EC ratios in the present study were higher than those observed in cities of the Pearl River Delta Region, which were between 1.0 and 4.0 in summer (Cao et al., 2004), but comparable to values from observations from other islands (Feng et al., 2007; Simoneit et al., 2004), and a cruise traversing the Northwest Pacific Ocean (Lim et al., 2003, Table 3).

The importance of SOC has been recognized for decades due to its impact on visibility, climate, and health; however, most studies have focused on urban areas (Cao et al., 2004; Feng et al., 2009; Weber et al., 2007) and there have been few studies on the remote marine atmosphere. A common method, which was introduced by Turpin (Turpin and Huntzicker, 1995) and developed by Castro (Castro et al., 1999), was used to quantify the contributions of primary organic carbon (POC) and SOC to total organic carbon (TOC). The equations can be expressed as follows:

$\mathrm{OC}_{\mathrm{sec}}=\mathrm{OC}_{\text {tot }}-\mathrm{OC}_{\mathrm{pri}}$

$\mathrm{OC}_{\mathrm{pri}}=\mathrm{EC} \times(\mathrm{OC} / \mathrm{EC})_{\mathrm{pri}}$

$\left(\mathrm{OC} / \mathrm{EC}_{\mathrm{pri}}\right)=\mathrm{EC} \times(\mathrm{OC} / \mathrm{EC})_{\min }$

where $\mathrm{OC}_{\mathrm{sec}}$ is SOC; $\mathrm{OC}_{\text {tot }}$ is TOC; $\mathrm{OC}_{\mathrm{pri}}$ is POC; and $(\mathrm{OC} / \mathrm{EC})_{\text {pri }}$ is the primary ratio estimate and can be calculated by $(\mathrm{OC} / \mathrm{EC})_{\min }$ (the minimum ratio of $\mathrm{OC}$ to $\mathrm{EC})$.

The $(\mathrm{OC} / \mathrm{EC})_{\min }$ ratios in PM2.5 were 1.1 in fall, 2.9 in winter, 1.5 in spring, and 2.3 in summer. In TSP, they were 1.9 in fall, 2.2 in winter, 1.8 in spring, and 1.7 in summer, respectively. These ratios were comparable with those observed at urban areas and rural sites; e.g., 1.3 at Aveiro and 2.6 at AreÀo (Castro et al., 1999). The average SOC concentrations in PM2.5 and TSP in each season were estimated using these $(\mathrm{OC} / \mathrm{EC})_{\min }$ ratios and are listed in Table 1. High SOC concentrations in PM2.5 were observed in fall $\left(2.3 \mu \mathrm{g} / \mathrm{m}^{3}\right)$ and spring $\left(1.5 \mu \mathrm{g} / \mathrm{m}^{3}\right)$, accounting for $63.9 \%$ and $48.4 \%$ of OC, respectively; while low SOC concentrations in PM2.5 occurred in summer $\left(0.8 \mu \mathrm{g} / \mathrm{m}^{3}\right)$ and winter $\left(0.9 \mu \mathrm{g} / \mathrm{m}^{3}\right)$, accounting for $80.0 \%$ and $23.1 \%$ of OC, respectively. The lowest contribution of SOC to OC occurred in winter and was mainly due to lower photochemical oxidation of precursors, such as VOC, under low ambient temperatures and solar radiation (Safai et al., 2014). The PM2.5/TSP ratio for SOC was also higher in fall (92.0\%) and spring (93.8\%), and lower in summer (88.9\%) and winter (50.0\%). Therefore, approximately $90 \%$ of SOC was concentrated in PM2.5 in the three seasons other than winter, indicating prominent SOC formation in coarse particles in winter.

3.4. Relationships between $O C$ and EC, OC and n-alkanes, and implications for sources

EC mainly originates from anthropogenic activity, and the relationship between $\mathrm{OC}$ and EC can be used to identify their sources; with a high correlation it is possible to assume a common
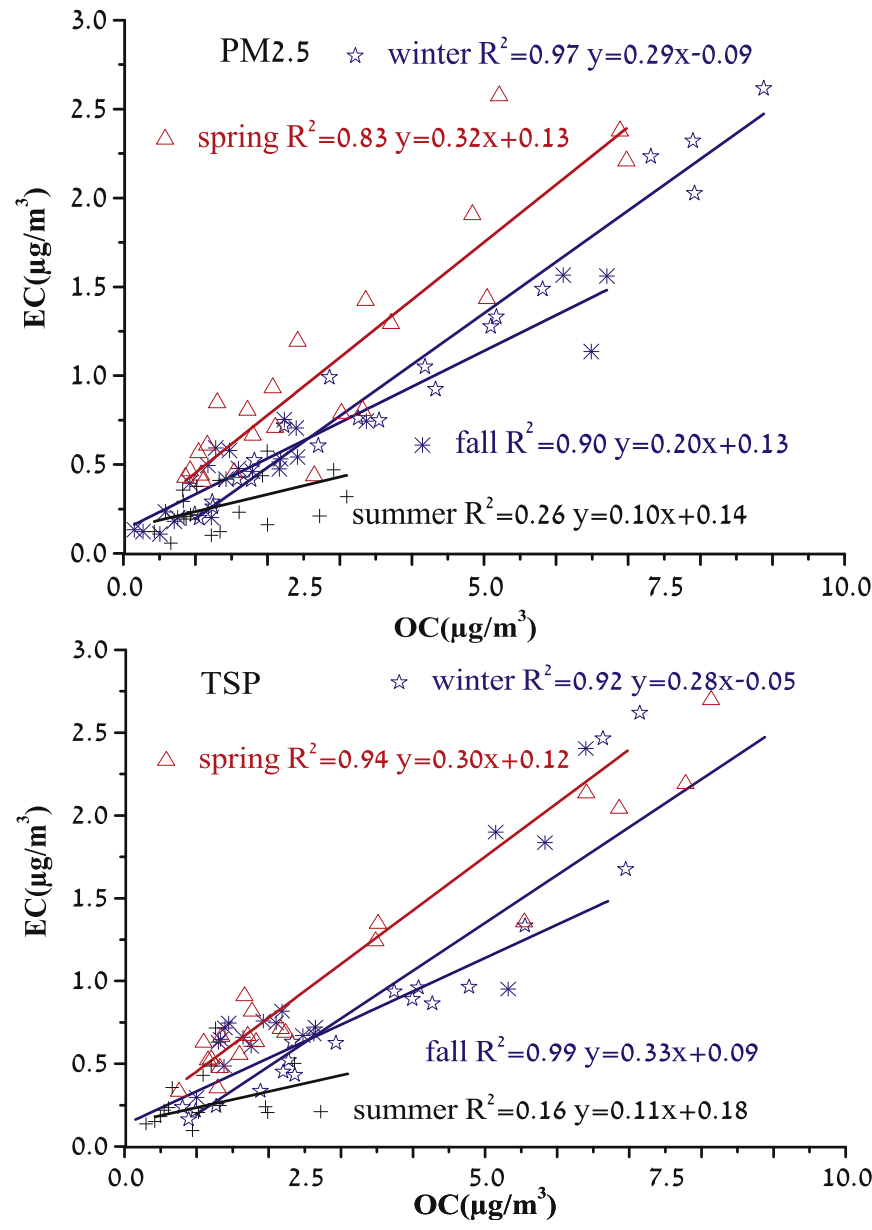

Fig. 7. Correlations between OC and EC in PM2.5 and TSP for each season. 
origin, commonly deriving from fossil-fuel combustion sources (Cao et al., 2005). Fig. 7 shows the correlation between OC and EC concentrations in PM2.5 and TSP over the four seasons. In PM2.5, strong correlations were observed in fall $\left(R^{2}=0.90\right)$, winter $\left(R^{2}=0.97\right)$, and spring $\left(R^{2}=0.83\right)$, suggesting a similar source for both OC and EC. However, the correlation in summer was only 0.26 for PM2.5, indicating an additional source of OC other than the common sources for EC, likely SOC formation through chemical reactions, such as photolytic oxidation (Richard et al., 2002). For TSP, positive correlations were also observed in fall, winter and spring $\left(\mathrm{R}^{2}=0.99,0.92\right.$, and 0.94 , respectively), and a poor correlation was observed in summer $\left(R^{2}=0.16\right)$.

Fig. 8 shows the seasonal correlations between OC and $n$-alkanes in PM2.5 and TSP. In both PM2.5 and TSP, OC displayed high correlations with $n$-alkanes in fall $\left(\mathrm{R}^{2}=0.75\right.$ and 0.58 , respectively), winter $\left(R^{2}=0.67\right.$ and 0.83 , respectively), and spring $\left(R^{2}=0.70\right.$ and 0.58 , respectively). This indicates that most $n$-alkanes had a common source with that of OC for the three seasons. In summer, however, this correlation was poor $\left(\mathrm{R}^{2}=0.32\right.$ and 0.05 , respectively), possibly due to $\mathrm{SOC}$ formation, especially in coarse particles (i.e., TSP-PM2.5). The dominance of high-carbon-number $n$-alkanes in spring and summer suggests that biogenic sources, especially epicuticular waxes from higher plants, were the predominant sources for these $n$-alkane compounds rather than anthropogenic emissions (Simoneit, 2002). According to Simoneit et al. (1991), the $n$-alkanes derived from plant waxes can be calculated from the following equation:

Wax $C_{n}=\left[\mathrm{Cn}-\left(\mathrm{C}_{\mathrm{n}+1}+\mathrm{C}_{\mathrm{n}-1}\right) / 2\right] / \mathrm{C}_{\mathrm{n}}$

Using Eq. (6), the average contribution from plant waxes to $n$ alkanes in TSP in spring was $20.5 \%$. In fall, winter, and summer, the contributions were $11.4 \%, 3.1 \%$, and $12.9 \%$, respectively. This indicates that plant waxes contributed higher concentrations of $n$ -
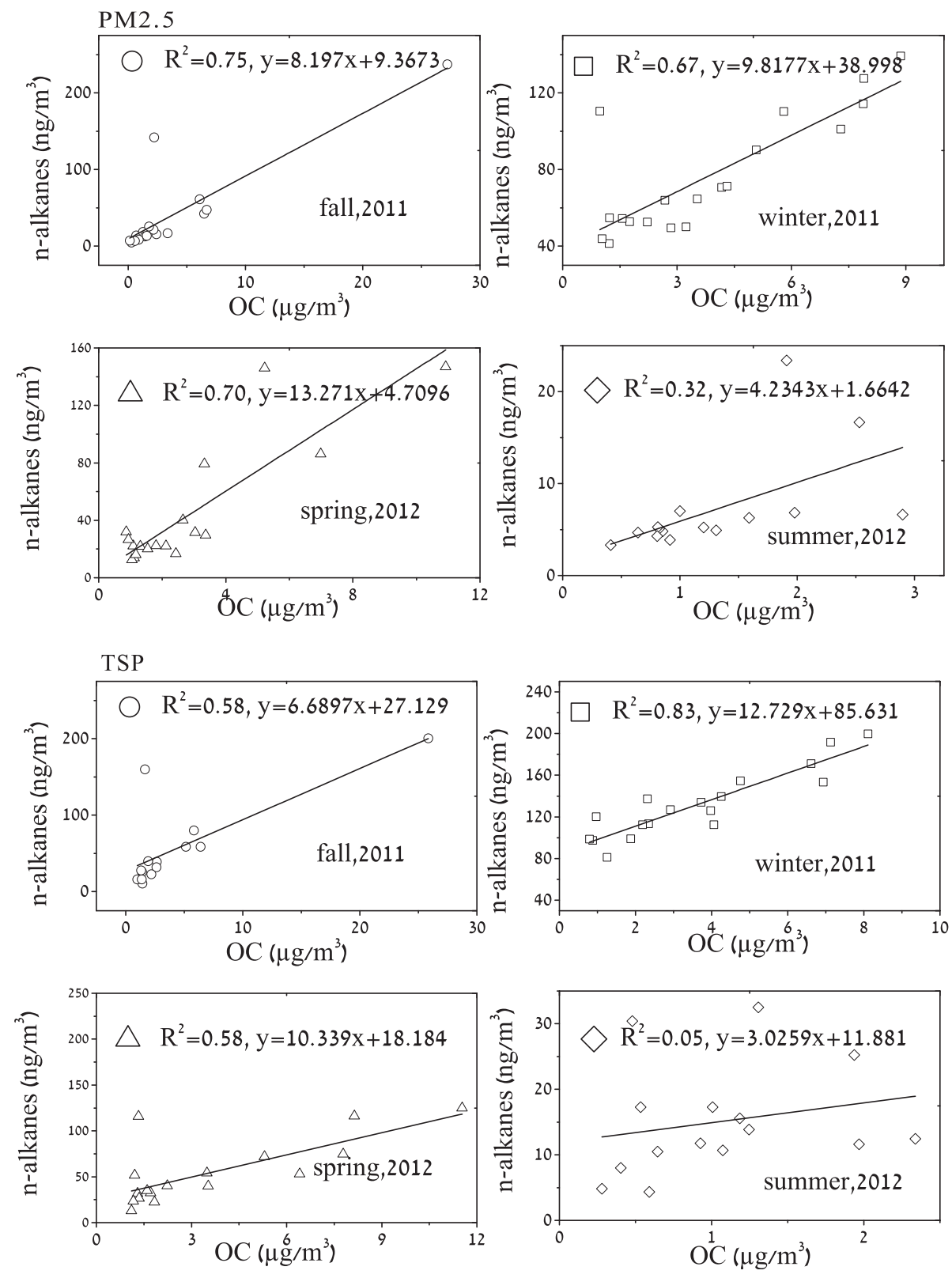

Fig. 8. Seasonal correlations of OC and $n$-alkanes in PM2.5 and TSP. 
alkanes in spring than in other seasons over the ECS. In spring, biogenic activities, such as the opening of leaves and production of pollen, are more common than in summer, and therefore contribute more $n$-alkanes. In fall and winter, the East Asian Monsoon brings more anthropogenic pollutants via long-range transport (see Section 3.3), thus decreasing the contribution of epicuticular wax from higher plants. Table 2 summarizes the ratio of wax-origin $n$-alkanes in PM2.5 and TSP in each season. The ratios in fall, winter, spring, and summer were $61.7 \%, 59.1 \%, 45.7 \%$, and $54.5 \%$, respectively, with an annual mean of $55.2 \%$. In fall and winter, the PM2.5/TSP ratio of the plant-wax-derived $n$-alkanes was $60.4 \%$, whereas in spring and summer, it was $50.1 \%$. The higher PM2.5/TSP ratios of the plant-wax-derived $n$-alkanes in fall and winter may be primarily caused by a greater quantity of petroleum residue residing in the TSP-PM2.5, as discussed in 3.2, which is possibly due to the long-range transport of the continental outflow.

\subsection{Episodic carbonaceous aerosols}

Three episodes of high concentrations of carbonaceous pollutants were observed in both PM2.5 and TSP in all seasons, with the exception of summer. To elucidate the origins and transport mechanisms of the carbonaceous pollutants during these episodes, 3-day air mass back-trajectories were calculated for each episode, shown by the red trajectories in Fig. 2: 11-13 November, 2011 (fall, 2011); 24-25 December, 2011 (winter, 2011), and 31 March and 3-5 April, 2012 (spring, 2012). Table 4 summarizes the concentrations and yields of TC (total carbon, $\mathrm{OC}+\mathrm{EC}, \mu \mathrm{g} / \mathrm{m}^{3}$ ) as well as the wax-origin $n$-alkanes $\left(\mathrm{ng} / \mathrm{m}^{3}\right)$ for PM2.5 and TSP for typical normal and episode days. Such comparisons reveal the organic chemical characteristics of the episode samples according to aerosol size.

For the fall episode, the average concentration of TC in TSP was $17.6 \mu \mathrm{g} / \mathrm{m}^{3}$; while the non-episode average was only $2.8 \mu \mathrm{g} / \mathrm{m}^{3}$. The PM2.5/TSP ratio for TC was $88.1 \%$, and on non-episode days this ratio was $71.4 \%$. Additionally, significantly higher PM2.5/TSP ratios for yield and wax-originated $n$-alkanes were observed for the episode (91.9\% and $68.0 \%$, respectively). This indicates that the carbonaceous pollutants in the episode were more concentrated in fine particles and their sources were distinctly different from those on non-episode days. As expected, the peak carbonaceous concentrations in the episode were associated with air masses from eastern China (Fig. 2) where biomass burning was taking place, and the emissions were carried in the air mass trajectory toward Huaniao Island (Wang et al., 2014), suggesting that the intensive biomass burning in eastern China was responsible for triggering the high-concentration episode, emitting high levels of PM2.5-bound carbonaceous pollutants.

For the winter episode, the average concentration of TC in TSP was $10.7 \mu \mathrm{g} / \mathrm{m}^{3}$, whereas for non-episode days it was only $5.4 \mu \mathrm{g} /$ $\mathrm{m}^{3}$. However, the PM2.5/TSP ratio for TC was $81.3 \%$, and on non- episode days the ratio was $79.6 \%$, remaining fairly constant thereafter. The PM2.5/TSP ratios for yield and wax-originated $n$-alkanes were also similar between episode and non-episode days. These results suggest that this episode perhaps brought high concentrations of carbonaceous pollutants, but with an undetectable influence on the particle size distribution. Therefore, the similar size distribution of carbonaceous pollutants between episode and nonepisode aerosol samples was possibly associated with SSA, which contributed more coarse aerosols mostly distributed in TSP-PM2.5. The back-trajectories during the episode traced back to northern China (Fig. 2) where coal and biomass burning were commonly used for indoor heating in winter (Tian et al., 2009). Furthermore, ambient temperatures were extremely low in northern China (http://www.tianqihoubao.com/weather/city.aspx) and Huaniao Island during this episode. Therefore, the higher levels of carbonaceous pollutants in the winter episode were probably due to the intensive indoor heating in North China under the cold air conditions.

For the spring episode, the average concentration of TC in TSP was $10.0 \mu \mathrm{g} / \mathrm{m}^{3}$; while the non-episode average was only $4.0 \mu \mathrm{g} / \mathrm{m}^{3}$. The PM2.5/TSP ratio for TC was $77.0 \%$, whereas the ratio on nonepisode days was $92.5 \%$. Similar to the TC, the PM2.5/TSP ratio for yield $n$-alkanes in the episode was higher than that on normal days (64.5\% and 59.7\%, respectively), and a lower PM2.5/TSP ratio was observed for waxed-originated $n$-alkanes in the episode. This indicates that the episode possibly played a significant role in determining the fraction of TC and wax-origin $n$-alkanes in the coarse particles. The air masses in the episode originated from remote northern China where Asian dust storm events frequently occur during the spring season (Guo et al., 2003; Zhang and Gao, 2007) (Fig. 2). Simoneit (1977) reported that dust samples transported long distances displayed odd-even dominance with high $\mathrm{C}_{\max }$ values $\left(\mathrm{C}_{29-31}\right)$, and high plant wax content in the $n$-alkanes. Guo et al. (2003) also observed a high plant wax contribution and higher $\mathrm{C}_{\max }$ in Asian dust storm samples collected in Qingdao, a coastal city in North China. Our TSP samples collected in the spring episode exhibited similar characteristics, whereas such characteristics were not seen in PM2.5. Therefore, the increased fraction of TC and wax-originated $n$-alkanes in the coarse particles during the episode was attributed to the influence from long-range transport of Asian dust storms.

\section{Conclusions}

This study presents a comprehensive data set on the concentrations, sources and general size distribution of carbonaceous aerosols over the ECS. The annual average concentration of carbonaceous aerosols over the ECS was $4.4 \mu \mathrm{g} / \mathrm{m}^{3}$ (OC: $3.3 \mu \mathrm{g} / \mathrm{m}^{3}$; EC: $1.1 \mu \mathrm{g} / \mathrm{m}^{3}$, respectively), and their concentration was highest in winter and lowest in summer. EC generally displayed a common source with that of $\mathrm{OC}$ in all seasons except summer. Petroleum

Table 4

Comparisons of average concentrations of TC and waxed-originated $n$-alkanes for PM2.5 and TSP between normal and episodic days.

\begin{tabular}{|c|c|c|c|c|c|c|c|c|c|c|}
\hline \multirow[t]{2}{*}{ Seasons } & & \multicolumn{3}{|l|}{$\begin{array}{l}\text { TC } \\
\mu \mathrm{g} / \mathrm{m}^{3}\end{array}$} & \multicolumn{3}{|c|}{$\begin{array}{l}\text { yield } n \text {-alkanes } \\
\mathrm{ng} / \mathrm{m}^{3}\end{array}$} & \multicolumn{3}{|c|}{$\begin{array}{l}\text { Plant wax } n \text {-alkanes } \\
\mathrm{ng} / \mathrm{m}^{3}\end{array}$} \\
\hline & & PM2.5 & TSP & $\begin{array}{l}\text { PM2.5/TSP } \\
\%\end{array}$ & PM2.5 & TSP & $\begin{array}{l}\text { PM2.5/TSP } \\
\%\end{array}$ & PM2.5 & TSP & $\begin{array}{l}\text { PM2.5/TSP } \\
\%\end{array}$ \\
\hline \multirow[t]{2}{*}{ Fall } & Normal & 2.0 & 2.8 & 71.4 & 23.6 & 42.62 & 55.4 & 3.1 & 7.0 & 44.3 \\
\hline & Episode & 15.5 & 17.6 & 88.1 & 106 & 115.3 & 91.9 & 10.2 & 15.0 & 68.0 \\
\hline \multirow[t]{2}{*}{ Winter } & Normal & 4.3 & 5.4 & 79.6 & 75.3 & 123.5 & 61.0 & 1.8 & 3.6 & 50.0 \\
\hline & Episode & 8.7 & 10.7 & 81.3 & 112.4 & 195.6 & 57.5 & 3.6 & 6.0 & 51.4 \\
\hline \multirow[t]{2}{*}{ Spring } & Normal & 3.7 & 4.0 & 92.5 & 28.7 & 48.1 & 59.7 & 4.9 & 9.7 & 50.5 \\
\hline & Episode & 7.7 & 10.0 & 77.0 & 71.8 & 111.3 & 64.5 & 7.3 & 21.1 & 34.6 \\
\hline
\end{tabular}


residue was the dominant contributor to the $n$-alkanes. A distinct composition pattern of $C_{14}-C_{20} n$-alkane dominance in winter was observed, likely due to the marine microbial contribution from SSA coupled with petroleum residue sources. A higher ratio of $\mathrm{POC} / \mathrm{OC}$ was observed in winter, indicating the cumulative impact of the continental outflow, associated with anthropogenic activities (e.g., vehicle emissions, biomass burning), and the prevailing meteorology. The POC was enhanced by prevailing meteorological conditions as well as the East Asian continental outflow. Three episodes of high concentrations of carbonaceous pollutants were examined to elucidate the effects of the East Asian continental outflow on the concentration, size distribution, and sources of carbonaceous aerosols over the ECS.

\section{Acknowledgements}

This work was supported by the National Basic Research Program of China (No: 2014CB953701), the Natural Science Foundation of China (NSFC) (No: 41176085) and Shanghai Science and Technology Committee (No: 12DJ1400102). We are most grateful to Prof. Xiaohong Yao of the Ocean University of China for his invaluable advices and comments. The anonymous reviewers should be sincerely appreciated for their constructive comments that greatly improved this study.

\section{Appendix A. Supplementary data}

Supplementary data related to this article can be found at http:// dx.doi.org/10.1016/j.atmosenv.2015.03.059.

\section{References}

Ault, A.P., Guasco, T.L., Baltrusaitis, J., Ryder, O.S., Trueblood, J.V., Collins, D.B., Ruppel, M.J., Cuadra-Rodriguez, L.A., Prather, K.A., Grassian, V.H., 2014. Heterogeneous reactivity of nitric acid with nascent sea spray aerosol: large differences observed between and within individual particles. J. Phys. Chem. Lett. 5, 2493-2500. http://dx.doi.org/10.1021/jz5008802.

Cao, J.J., Chow, J.C., Lee, S.C., Li, Y., Chen, S., An, Z.S., Fung, K., Watson, J., Zhu, C., Liu, S., 2005. Characterization and source apportionment of atmospheric organic and elemental carbon during fall and winter of 2003 in Xi'an, China. Atmos. Chem. Phys. 5, 3127-3137.

Cao, J.J., Lee, S.C., Ho, K., Zou, S., Fung, K., Li, Y., Watson, J., Chow, J.C., 2004. Spatial and seasonal variations of atmospheric organic carbon and elemental carbon in pearl river delta region, China. Atmos. Environ. 38, 4447-4456.

Castro, L., Pio, C., Harrison, R.M., Smith, D., 1999. Carbonaceous aerosol in urban and rural European atmospheres: estimation of secondary organic carbon concentrations. Atmos. Environ. 33, 2771-2781.

Chow, J.C., Watson, J., Lu, Z., Lowenthal, D., Frazier, C., Solomon, P., Thuillier, R., Maglinao, K., 1996. Descriptive analysis of PM2.5 and PM10 at regionally representative locations during SJVAQS/AUSPEX. Atmos. Environ. 30, 2079-2112.

Chow, J.C., Watson, J., Pritchett, L., Pierson, W., Frazier, C., Purcell, R., 1993. The DRI thermal/optical reflectance carbon analysis system: description, evaluation and applications in US air quality studies. Atmos. Environ. 27, 1185-1201.

Duce, R., Unni, C., Ray, B., Prospero, J., Merrill, J., 1980. Long-range atmospheric transport of soil dust from Asia to the tropical North Pacific: temporal variability. Science 209, 1522.

Feng, J.L., Guo, Z.G., Chan, C.K., Fang, M., 2007. Properties of organic matter in $\mathrm{PM}_{2.5}$ at Changdao Island, China-A rural site in the transport path of the Asian continental outflow. Atmos. Environ. 41, 1924-1935.

Feng, J.L., Hu, M., Chan, C.K., Lau, P.S., Fang, M., He, L.Y., Tang, X.Y., 2006 A comparative study of the organic matter in PM2.5 from three Chinese megacities in three different climatic zones. Atmos. Environ. 40, 3983-3994.

Feng, Y.L., Chen, Y.J., Guo, H.Z., Li, J., Sheng, G.Y., Fu, J.M., 2009. Characteristics of organic and elemental carbon in PM2.5 samples in Shanghai, China. Atmos. Res. 92, 434-442.

Gao, Y., Arimoto, R., Duce, R., Zhang, X., Zhang, G., An, Z., Chen, L., Zhou, M., Gu, D., 1997. Temporal and spatial distributions of dust and its deposition to the China Sea. Tellus B 49, 172-189.

Grimalt, J., Albaiges, J., 1987. Sources and occurrence of $C_{12}-C_{22} n$-alkane distributions with even carbon-numbe preference in sedimentary environments. Geochim. Cosmochim. Acta 51, 1379-1384.

Gustafsson, Ö., Kruså, M., Zencak, Z., Sheesley, R.J., Granat, L., Engström, E., Praveen, P., Rao, P., Leck, C., Rodhe, H., 2009. Brown clouds over South Asia: biomass or fossil fuel combustion? Science 323, 495-498.
Guo, L., Chen, Y., Wang, F.J., Meng, X., Xu, Z.F., Zhuang, G.S., 2014. Effects of Asian dust on the atmospheric input of trace elements to the East China Sea. Mar. Chem. 163, 19-27.

Guo, Z.G., Sheng, L.F., Feng, J.L., Fang, M., 2003. Seasonal variation of solvent extractable organic compounds in the aerosols in Qingdao, China. Atmos. Environ. 37, 1825-1834.

Guo, Z.G., Lin, T., Zhang, G., Hu, L.M., Zheng, M., 2009. Occurrence and sources of polycyclic aromatic hydrocarbons and n-alkanes in PM2.5 in the roadside environment of a major city in China. J. Hazard. Mater. 170, 888-894.

Harji, R.R., Yvenat, A., Bhosle, N.B., 2008. Sources of hydrocarbons in sediments of the mandovi estuary and the marmugoa harbour, west coast of India. Environ. Inter 34, 959-965.

He, K.B., Yang, F., Ma, Y., Zhang, Q., Yao, X.H., Chan.C., Cadle.S., Chan, T., Mulawa, P., 2001. The characteristics of PM2.5 in Beijing, China. Atmos. Environ. 35, 4959-4970.

Highwood, E.J., Kinnersley, R.P., 2006. When smoke gets in our eyes: the multiple impacts of atmospheric black carbon on climate, air quality and health. Environ. Inter. 32, 560-566.

Hsu, S.C., Liu, S., Arimoto, R., Liu, T., Huang, Y., Tsai, F., Lin, F., Kao, S., 2009. Dust deposition to the East China Sea and its biogeochemical implications. J. Geophys. Res. 114, D15304. http://dx.doi.org/10.1029/2008JD01122.

Hsu, S.C., Wong, G., Gong, G., Shiah, F., Huang, Y., Kao, S., Tsai, F., Lung, S., Lin, F. Lin, I., 2010. Sources, solubility, and dry deposition of aerosol trace elements over the East China Sea. Mar. Chem. 120, 116-127.

Hu, L.M., Shi, X.F., Yu, Z.G., Lin, T., Wang, H.J., Ma, D.Y., Guo, Z.G., Yang, Z.S., 2012. Distribution of sedimentary organic matter in estuarine- inner shelf regions of the East China Sea: implications for hydrodynamic forces and anthropogenic impact. Mar. Chem. 142-144, 29-40.

Huebert, B., Bertram, T., Kline, J., Howell, S., Eatough, D., Blomquist, B., 2004 Measurements of organic and elemental carbon in Asian outflow during ACEAsia from the NSF/NCAR C-130. J. Geophys. Res. 109, D19S11. http:// dx.doi.org/10.1029/2004JD004700.

Kaneyasu, N., Takada, H., 2004. Seasonal variations of sulfate, carbonaceous species (black carbon and polycyclic aromatic hydrocarbons), and trace elements in fine atmospheric aerosols collected at subtropical islands in the East China Sea. J. Geophys. Res. 109, D06211. http://dx.doi.org/10.1029/2003JD004137.

Lim, H.J., Turpin, B., Russell, L., Bates, T., 2003. Organic and elemental carbon measurements during ACE-Asia suggest a longer atmospheric lifetime for elemental carbon. Environ. Sci. Technol. 37, 3055-3061.

Lin, T., Hu, L.M., Guo, Z.G., Qin, Y.W., Yang, Z.S., Zhang, G., Zheng, M., 2011. Sources of polycyclic aromatic hydrocarbons to sediments of the Bohai and Yellow Seas in East Asia. J. Geophys. Res. 116, D23305. http://dx.doi.org/10.1029/2011JD015722.

Lin, T., Hu, L.M., Guo, Z.G., Zhang, G., Yang, Z.S., 2013. Deposition fluxes and fate of polycyclic aromatic hydrocarbons in the Yangtze river estuarine-inner shelf in the East China Sea. Glob. Biogeochem. Cycles 27, 77-87. http://dx.doi.org/ 10.1029/2012 GB004317.

Menon, S., Hansen, J., Nazarenko, L., Luo, Y., 2002. Climate effects of black carbon aerosols in China and India. Science 297, 2250-2253.

Nilsson, E.D., Rannik, U., Swietlicki, E., Leck, C., Aalto, P.P., Zhou, J., Norman, M., 2001 Turbulent aerosol fluxes over the Arctic Ocean: 2. Wind-driven sources from the sea. J. Geophys. Res. 106, 32,139-32,154. http://dx.doi.org/10.1029/ $2000 J D 900747$.

O'Dowd, C.D., Smith, M.H., 1993. Physicochemical properties of aerosols over the northeast Atlantic: evidence for wind-speed-related submicron sea-salt aerosol production. J. Geophys. Res. 98, 1137-1149. http://dx.doi.org/10.1029/ 92JD02302.

Rajput, P., Sarin, M.M., Rengarajan, R., Singh, D., 2011. Atmospheric polycyclic aromatic hydrocarbons (PAHs) from post-harvest biomass burning emissions in the Indo-Gangetic plain: isomer ratios and temporal trends. Atmos. Environ. 45 6732-6740.

Richard, T., Hildemann, L., Kamens, R., Lee, S., Malm, W., Pandis, S., Pankow, J., Schauer, J., Watson, J., Zielinska, B., 2002. Secondary Organic Aerosols Research Strategy to Apportion Biogenic/anthropogenic Sources: an Outcome of the First Secondary Organic Aerosols Workshop, February 4-5, 2002. Fort Lewis College Durango, CO. Desert Research Institute, Reno, NV.

Saarikoski, S., Timonen, H., Saarnio, K., Aurela, M., Jarvi, L., Keronen, P., Kerminen, V.-M., Hillamo, R., 2008. Sources of organic carbon in fine particulate matter in northern European urban air. Atmos. Chem. Phys. 8, 6281-6295.

Salter, M.E., Nilsson, E.D., Butcher, A., Bilde, M., 2014. On the seawater temperature dependence of the sea spray aerosol generated by a continuous plunging jet. J. Geophys. Res. Atmos. 119, 9052-9072. http://dx.doi.org/10.1002 2013JD021376.

Safai, P.D., Raju, M.P., Rao, P.S.P., Pandithurai, G., 2014. Characterization of carbonaceous aerosols over the urban tropical location and a new approach to evaluate their climatic importance. Atmos. Environ. 92, 493-500.

Schauer, J.J., Kleeman, M.J., Cass, G.R., Simoneit, B.R.T., 2002. Measurement of emissions from air pollution sources. 5. C1-C32 organic compounds from gasoline-powered motor vehicles. Environ. Sci. Technol. 36, 1169-1180.

Schmidt, M., Skjemstad, J., Czimczik, C., Glaser, B., Prentice, K., Gelinas, Y. Kuhlbusch, T., 2001. Comparative analysis of black carbon in soils, global. Biogeochem. Cycles 15, 163-167.

Simoneit, B.R., 1977. Organic matter in eolian dusts over the Atlantic Ocean. Mar Chem. 5, 443-464.

Simoneit, B.R., 1986. Characterization of organic constituents in aerosols in relation to their rigin and transport: a review. Inter. J. Environ. Ana. Chem. 23, 207-237. 
Simoneit, B.R., 2002. Biomass burning - a review of organic tracers for smoke from incomplete combustion. Appl. Geochem. 17, 129-162.

Simoneit, B.R., Kobayashi, M., Mochida, M., Kawamura, K., Lee, M., Lim, H., Turpin, B. Komazaki, Y., 2004. Composition and major sources of organic compounds of aerosol particulate matter sampled during the ACE-Asia campaign. J. Geophys. Res. 109, D19S10. http://dx.doi.org/10.1029/2004JD004598.

Simoneit, B.R., Sheng, G.Y., Chen, X.J., Fu, J.M., Zhang, J., Xu, Y.P., 1991. Molecular marker study of extractable organic matter in aerosols from urban areas of China. Atmos. Environ. 25A, 2111-2129.

Tian, F.L., Chen, J.W., Qiao, X.L., Wang, Z., Yang, P., Wang, D., Ge, L., 2009. Sources and seasonal variation of atmospheric polycyclic aromatic hydrocarbons in Dalian, China: factor analysis with non-negative constraints combined with loca source fingerprints. Atmos. Environ. 43, 2747-2753.

Turpin, B., Huntzicker, J., 1995. Identification of secondary organic aerosol episodes and quantitation of primary and secondary organic aerosol concentrations during SCAQS. Atmos. Environ. 29, 3527-3544.
Wang, F.W., Lin, T., Li, Y.Y., Ji, T.Y., Ma, C.L., Guo, Z.G., 2014. Sources of polycyclic aromatic hydrocarbons in PM2.5 over the East China Sea, a downwind domain of East Asian continental outflow. Atmos. Environ. 92, 484-492.

Weber, R.J., Sullivan, A.P., Peltier, R.E., Russell, A., Yan, B., Zheng, M., Gouw, J., Warneke, C., Brock, C., Holloway, J.S., Atlas, E.L., Edgerton, E., 2007. A study of secondary organic aerosol formation in the anthropogenic-influenced southeastern United States. J. Geophys. Res. 112, D13302. http://dx.doi.org/10.1029/ 2007JD008408.

Woodcock, A.H., 1953. Salt nuclei in marine air as a function of altitude and wind force. J. Meteorol. 10, 362-371.

Zhang, K., Gao, H.W., 2007. The characteristics of Asian-dust storms during 2000-2002: from the source to the sea. Atmos. Environ. 41, 9136-9145.

Zhang, Y., Yu, Q., Ma, W.C., Chen, L.M., 2010. Atmospheric deposition of inorganic nitrogen to the eastern China seas and its implications to marine biogeochemistry. J. Geophys. Res. 115, D00K10. http://dx.doi.org/10.1029/ 2009JD012814. 